\title{
Mapping amino acid and short-chain fatty acid metabolism in man
}

Citation for published version (APA):

Neis, E. (2019). Mapping amino acid and short-chain fatty acid metabolism in man: role of the gut microbiota. [Doctoral Thesis, Maastricht University]. ProefschriftMaken. https://doi.org/10.26481/dis.20191023en

Document status and date:

Published: 01/01/2019

DOI:

10.26481/dis.20191023en

Document Version:

Publisher's PDF, also known as Version of record

\section{Please check the document version of this publication:}

- A submitted manuscript is the version of the article upon submission and before peer-review. There can be important differences between the submitted version and the official published version of record.

People interested in the research are advised to contact the author for the final version of the publication, or visit the DOI to the publisher's website.

- The final author version and the galley proof are versions of the publication after peer review.

- The final published version features the final layout of the paper including the volume, issue and page numbers.

Link to publication

\footnotetext{
General rights rights.

- You may freely distribute the URL identifying the publication in the public portal. please follow below link for the End User Agreement:

www.umlib.nl/taverne-license

Take down policy

If you believe that this document breaches copyright please contact us at:

repository@maastrichtuniversity.nl

providing details and we will investigate your claim.
}

Copyright and moral rights for the publications made accessible in the public portal are retained by the authors and/or other copyright owners and it is a condition of accessing publications that users recognise and abide by the legal requirements associated with these

- Users may download and print one copy of any publication from the public portal for the purpose of private study or research.

- You may not further distribute the material or use it for any profit-making activity or commercial gain

If the publication is distributed under the terms of Article $25 \mathrm{fa}$ of the Dutch Copyright Act, indicated by the "Taverne" license above, 
Summary 



\section{Summary}

Obesity has grown to epidemic proportions worldwide and is strongly related to type 2 diabetes, heart disease, and several types of cancer. In a few years, global obesity prevalence will reach $18 \%$ in men and surpass $21 \%$ in women while severe obesity will surpass $6 \%$ in men and $9 \%$ in women. As such, the obesity epidemic is becoming a major driver of future healthcare costs internationally. Besides, it also affects worker productivity and could constrain future economic development if not effectively addressed. In order to counter this obesity epidemic, there is an urgent need to understand the mechanisms underlying the development of obesity and its progression.

It is known that the fundamental cause of obesity and overweight arises from an energy imbalance; an increased intake of energy-dense foods high in fat in combination with a decrease in physical activity. However, recent studies also demonstrated an essential role for the gut microbiota in the development of obesity and its comorbidities. In fact, the functional output of the gut microbiota, in particular short-chain fatty acids and amino acids, seems to affect metabolic homeostasis profoundly. Therefore, changing the gut microbiota composition and its metabolic activity is considered an attractive option to tackle diseases. However, evidence concerning the metabolic effects of microbial products in humans is rather scarce. This thesis therefore focuses on the role of gut microbial dysbiosis in the aetiology of obesity, with particular interest in the fate of microbial products in the human body.

The main goals of this project were to explore the impact of antibiotics on the gut microbial composition in the short versus the long term and to study whether manipulation of the gut microbiota impacts host metabolism. In addition, the impact of antibiotics on gutderived microbial products, in particular the branched-chain amino acids, was assessed. Finally, the interorgan exchange of microbial products was assessed in a human setting.

Chapter 2 reviews the available evidence on the contribution of microbial amino acids to host amino acid homeostasis, and the role of the gut microbiota as a determinant of amino acid and short-chain fatty acid perturbations in human obesity and type 2 diabetes mellitus. As part of the major nutrients in the diet, amino acids should be particularly taken into account since they not only support the growth and survival of bacteria in the gastrointestinal tract, but also regulate energy and protein homeostasis in multicellular organisms. An early study by Whitt and colleagues already contributed to the hypothesis that gut bacteria may play an important role in host amino acid homeostasis and health by showing that germ free mice had an altered distribution of free amino acids along the gastrointestinal tract as compared to conventionalized mice. Along the gastrointestinal tract, alimentary and endogenous proteins are hydrolyzed into peptides and amino acids by host- and bacteria-derived proteases and peptidases. The released peptides and amino acids can be further utilized by both gut bacteria and the host or serve as precursors for the synthesis of short-chain fatty acids, which play a role in the development of obesity. As a consequence, the disruption in gut microbiota composition that has been implicated 
in the pathogenesis of obesity, insulin resistance, and type 2 diabetes mellitus may alter the bioavailability of amino acids to the host. This could have significant implications in the context of insulin resistance and type 2 diabetes mellitus, conditions characterized by elevated systemic concentrations of certain (precursor) amino acids, in particular the aromatic and branched-chain amino acids. The altered bacterial composition in the gut as observed in obese subjects with type 2 diabetes may therefore play a major role in their metabolic derangements by influencing amino acid and SCFA bioavailability to the host.

In Chapter 3, it is shown that a seven-day antibiotic treatment affected gut microbiota composition although it did not significantly affect host metabolism in 57 obese, insulin resistant males as compared to a placebo group. Subjects were randomly assigned to ingest $1500 \mathrm{mg}$ /day amoxicillin (AMOX; broad-spectrum antibiotic), vancomycin (VANCO; aimed at Gram-positive bacteria), or placebo (PLA; microcrystalline cellulose) for 7 days. Surprisingly, this short-term antibiotic treatment did neither affect whole-body insulin sensitivity nor hepatic, peripheral, or adipose tissue insulin sensitivity. The same lack of effect was found for fasting and/or postprandial energy expenditure, energy harvest, and substrate utilization as well as gut permeability. In addition, no significant changes in circulating glucose, insulin, triacylglycerol, free fatty acids, GLP-1, leptin, and lipopolysaccharide binding protein (LPB) concentrations were observed. Nonetheless, a pronounced decrease in bacterial diversity and a reduction of Firmicutes abundance upon VANCO treatment was found, but not upon AMOX treatment. Consequently, decreased plasma and/or fecal concentrations of SCFA and bile acid metabolites were observed. Despite the fact that the altered microbial composition was still present at 8 weeks follow-up, no significant effect on human metabolism at this timepoint was detected. In conclusion, these data demonstrated that manipulation of the human gut microbiota composition in obese, insulin resistant men by antibiotics did not profoundly affect host metabolism. The lack of metabolic effects could be related to the short exposure to antibiotics, as compared with the time needed to affect host metabolism. Another interesting point to address is that this study investigated metabolically compromised individuals but also used an array instead of deep sequencing methods to profile the gut microbiota, potentially ignoring changes in bacteria not represented by corresponding probes. In view of these data, there is a need for longer term intervention studies in humans with state-of-the-art microbiota analysis techniques to investigate if gut microbiota manipulations can contribute to altered human metabolism during obesity.

Chapter 4 focused on the effects of short-term antibiotic treatment on plasma amino acid levels since there is an increasing body of evidence that bacterial amino acids are important modulators underlying the development of obesity. This study demonstrated that AMOX treatment specifically increased plasma BCAA levels compared to PLA, whilst VANCO treatment did not show any significant effects on plasma BCAA levels. Importantly, only VANCO treatment affected the gut microbial composition significantly with a decrease in the relative abundance of mainly Gram-positive bacteria of the 
Firmicutes phylum. Conversely, Gram-negative bacteria showed an increased relative abundance after VANCO treatment. Since intestinal bacteria can degrade BCAA, it may be possible that the shift in the gut microbiota composition upon VANCO treatment is responsible for a higher degradation of BCAA in that group. In fact, bacteria harbor highly active peptidases. Regarding the colon, it appears that amino acids including lysine, arginine, glycine, and the BCAA leucine, valine, and isoleucine are the preferred substrates of colonic bacteria. Whether this influenced host BCAA availability remains to be determined. As such, future studies should explore the mechanisms driving altered BCAA concentrations by short-term antibiotics treatment and its relationship with insulin resistance. As mentioned before, the use of a microarray in our study to profile the gut microbiota may have prevented the detection of certain microbial changes in the AMOX group that could be related to increased BCAA concentrations.

Since knowledge about the exchange of amino acids across abdominal organs in humans is scarce, a comprehensive overview of human amino acid metabolism is given in Chapter 5. In view of the increasingly acknowledged role of the gut microbiota in amino acid metabolism and energy metabolism, special attention was paid to the differences in amino acid handling between the large intestine and the small intestine. The inter-organ trafficking of amino acids was investigated in a surgical setting in which twenty patients underwent upper abdominal surgery. During surgery, blood was simultaneously sampled from the radial artery and several veins (portal vein, hepatic vein, superior mesenteric vein, inferior mesenteric vein, splenic vein, renal vein). This provided the opportunity to quantify the contribution of the distal ileum together with the proximal colon, distal colon, portal drained viscera, splanchnic area, liver, spleen, and kidneys in producing or extracting amino acids. The data revealed that the well-known intestinal glutamine-citrulline pathway appears to be functional in the distal ileum and proximal colon but not in the distal colon. The overall finding that the distal colon only showed minor arteriovenous differences is interesting in view of the suggested role of colonic bacteria in amino acid metabolism. It may well be that amino acids are not significantly absorbed by the colonic mucosa, but rather intensively metabolized by the colonic microbiota. Partly due to differences in microbiota abundance and composition along the gastrointestinal tract, bacterial amino acid metabolism in the gut is likely to be compartment specific. In light of the health claims of pre- and probiotics, the current study provided a detailed picture of the physiology of human amino acid metabolism. As a follow-up to this study and the ever increasing interest in functional foods that affect the composition of the gut microbiota and its functional output, the inter-organ handling of SCFA in this unique human model was also investigated, and presented in Chapter 6. It appears that the distal colon is the major releasing site of SCFA in vivo in humans followed by the proximal colon which contributed only a third of the SCFA release by the distal colon into the systemic circulation. This may indicate that a larger part of SCFA are metabolized by the intestinal mucosa of the proximal colon as most SCFA production occurs in this part of the colon. The fact that the gut microbiota composition and activity differ between the proximal and distal colon may contribute to the present findings. Additionally, it is known that the SCFA receptors GPR41 and 
GPR43 are mainly expressed in the distal ileum and ascending colon. Hence, a recent study indicated the distal colon to be the most suitable location to elicit beneficial effects for host metabolism as distal, not proximal, administered acetate induced a pronounced increase in fasting fat oxidation and circulating concentrations of the satiety-stimulating hormone peptide YY. Taken together, these findings may give leads for the development of nutritional strategies and food products specifically modulating SCFA production in the distal part of the colon, thereby beneficially affecting metabolic health. Finally, intestinally produced SCFA did not escape the splanchnic area as concluded by hepatic vein concentrations indicating efficient hepatic clearance of SCFA.

As the liver turned out to be an important organ scavenging nearly all SCFA within the circulation, the question arose what impact a situation of acute loss of liver function would have on systemic SCFA concentrations. High systemic concentrations of butyrate, for example, can cause side effects such as hypokalemia and nausea. In Chapter 7, hepatic SCFA clearance was studied upon an acute, although controlled, loss of liver function in humans. In this study, blood was sampled from the radial artery, portal vein, and hepatic vein before and after hepatic resection in 30 patients undergoing partial liver resection. It was shown that the gut produced significant amounts of acetate, propionate, and butyrate, which did not change after partial hepatectomy. Whereas hepatic propionate uptake did not differ significantly before and after resection, hepatic acetate and butyrate uptake increased significantly upon partial liver resection. As such, arterial SCFA concentrations were not different before and after partial liver resection. In conclusion, acute hepatic tissue loss did not influence systemic concentrations of SCFA, implying that the liver has a large reserve capacity to metabolize propionate, acetate, and butyrate to prevent any increase of arterial concentrations. This was underscored by the increased hepatic uptake of acetate and butyrate after partial liver resection which, in turn, may be interpreted as circumstantial evidence for the safety of prebiotic supplementation even in patients with limited liver tissue.

In Chapter 8, the main findings of the studies presented in this thesis are described and integrated. First, the antibiotic trial (presented in Chapter 3 and 4) provided unique data of patients during a randomized doubleblind placebocontrolled intervention. This study, however, did not provide evidence that altering the gut microbiota impacts human metabolic regulation, although there are numerous studies which have associated changes in gut microbiota composition and metabolites with host metabolism. Future research is therefore needed to validate the potential of gut microbiota manipulation in different metabolic phenotypes. Ideally, metagenomics would be applied in these studies to identify specific changes in metabolic microbiota pathways. Additionally, more clinical research is required to improve our understanding of the possibility and feasibility of manipulating the human microbiota using prebiotics as an approach to promote health or treat and prevent disease. In that regard, it may be of interest to administer prebiotics to patients undergoing surgery followed by blood sampling in multiple splanchnic vessels. In this way, it can be investigated how prebiotics affect SCFA and AA interorgan exchange in the short-term. Additionally, this might give 
insight into the effects of prebiotics on colonic physiology as it will be possible to obtain intestinal biopsies during surgery. 



\section{Samenvatting}





\section{Samenvatting}

Obesitas heeft wereldwijd epidemische proporties aangenomen en is sterk gerelateerd aan diabetes mellitus type 2, hartaandoeningen en verschillende soorten kanker. Over een paar jaar zal $18 \%$ van de mannen en $21 \%$ van de vrouwen wereldwijd kampen met obesitas, terwijl $6 \%$ van de mannen en $9 \%$ van de vrouwen wereldwijd zelfs met ernstige obesitas te maken krijgt. Deze obesitas-epidemie zal een belangrijke oorzaak worden van toekomstige zorgkosten. Bovendien beïnvloedt het de productiviteit van werknemers en kan het de toekomstige economische ontwikkeling belemmeren als het niet effectief wordt aangepakt. Om deze obesitasepidemie tegen te gaan is er dringend behoefte aan inzicht in de mechanismen die ten grondslag liggen aan de ontwikkeling van obesitas en de progressie ervan. Obesitas is het gevolg van een verstoorde energiebalans; d.w.z. een verhoogde inname van energierijk voedsel in combinatie met lichamelijke inactiviteit. Recente studies wijzen echter ook op een rol voor de darmflora in de ontwikkeling van obesitas en comorbiditeiten. In feite lijken met name de metabolieten van de darmflora, in het bijzonder de korte keten vetzuren en aminozuren, de metabole homeostase van de gastheer diepgaand te beïnvloeden. Daarom wordt interferentie met de samenstelling van de darmflora, en daarmee ook de metabole activiteit ervan, beschouwd als een aantrekkelijke manier om ziekten aan te pakken. Bewijs hiervoor in mensen is echter schaars. Dit proefschrift richt zich daarom op de rol van microbiële dysbiose in de etiologie van obesitas, met bijzondere belangstelling voor het lot van de microbiële producten in het menselijk lichaam.

De hoofddoelen van dit project waren te onderzoeken wat de impact van antibiotica is op de microbiële samenstelling van de darm (op korte en lange termijn) en of manipulatie van de darmflora invloed heeft op het metabolisme van de gastheer. Bovendien werd het effect van antibiotica op bepaalde microbiële producten, de zogenaamde vertakte keten aminozuren, bestudeerd. Ten slotte werd de uitwisseling van microbiële producten tussen de abdominale organen onderzocht in patiënten.

In Hoofdstuk 2 wordt de bijdrage van het microbiële aminozuurmetabolisme aan de eiwithomeostase die in het menselijke lichaam heerst beschreven. Zo ook wordt de rol van de darmflora als determinant van aminozuur- en korte-keten vetzuur verstoringen in obesitas en diabetes mellitus type 2 beschreven. Als onderdeel van de belangrijkste voedingsstoffen in het dieet, moet duidelijk rekening worden gehouden met aminozuren, omdat ze niet alleen de groei en overleving van bacteriën in het maagdarmkanaal ondersteunen, maar ook de energie- en eiwithomeostase in meercellige organismen reguleren. Een studie gepubliceerd door Dhr. Whitt en collega's droeg reeds bij aan de hypothese dat darmbacteriën een belangrijke rol kunnen spelen bij de eiwithomeostase in de gastheer. Zij toonden namelijk aan dat kiemvrije muizen een veranderde verdeling van aminozuren lieten zien in het maagdarmkanaal in vergelijking met muizen met een conventionele darmflora. Binnen het maagdarmkanaal worden zowel exogene- als endogene eiwitten afgebroken tot peptiden en aminozuren door van de gastheer en van 
bacteriën afkomstige proteasen en peptidasen. De vrijgekomen peptiden en aminozuren kunnen verder worden gebruikt door zowel darmbacteriën als de gastheer of dienen als voorlopers voor de synthese van korte keten vetzuren, die tevens een rol spelen bij de ontwikkeling van obesitas. Een verstoring van de samenstelling van de darmflora welke gelinkt is aan de pathogenese van obesitas, insulineresistentie en diabetes mellitus type 2 zou mogelijk de biologische beschikbaarheid van aminozuren in de gastheer kunnen beïnvloeden. Dit kan significante implicaties hebben in de context van insulineresistentie en diabetes mellitus type 2, aandoeningen die worden gekenmerkt door verhoogde systemische concentraties van bepaalde aminozuren, in het bijzonder de aromatische en vertakte keten aminozuren. De veranderde bacteriesamenstelling in de darm, zoals waargenomen bij zwaarlijvige personen met diabetes mellitus type 2, kan daarom een belangrijke rol spelen in de metabole stoornissen in deze personen doordat de veranderde bacteriesamenstelling mogelijk de biologische beschikbaarheid van aminozuren en korte keten vetzuren beïnvloed.

In Hoofdstuk 3 wordt beschreven hoe een zevendaagse antibioticakuur de samenstelling van de darmflora beïnvloedde, hoewel het geen significante invloed had op het metabolisme van 57 zwaarlijvige, insulineresistente mannen in vergelijking met een placebogroep. De proefpersonen werden willekeurig toegewezen om $1500 \mathrm{mg} / \mathrm{dag}$ amoxicilline (breedspectrum antibioticum gericht op zowel Gram-positieve als Gramnegatieve bacteriën), vancomycine (gericht op Gram-positieve bacteriën) of placebo (microkristallijne cellulose) gedurende 7 dagen in te nemen. Verrassenderwijs had deze korte behandeling met antibiotica geen invloed op de algehele insulinegevoeligheid van het lichaam, noch op de insuline gevoeligheid in specifiek lever- en vetweefsel. Hetzelfde gold voor de energie opbrengst, het energie- en substraatverbruik en de darmpermeabiliteit welke allemaal onveranderd bleven in zowel gevaste als gevoede toestand. Bovendien werden geen significante veranderingen waargenomen in de concentraties van glucose, insuline, triacylglycerol, vrije vetzuren, GLP-1, leptine en lipopolysaccharide-bindend eiwit (LPB). Desalniettemin werd een uitgesproken afname in bacteriediversiteit met een afname in de hoeveelheid Firmicutes gevonden na toediening van het antibioticum vancomycine, maar niet na behandeling met amoxicilline. Bovendien werden verlaagde plasma- en/of fecale concentraties van korte keten vetzuren en galzuurmetabolieten waargenomen. Ondanks het feit dat de veranderde microbiële samenstelling nog steeds aanwezig was na 8 weken follow-up, werd op dit tijdstip geen significant effect op het menselijke metabolisme gedetecteerd. Concluderend toonden deze gegevens aan dat manipulatie van de samenstelling van de darmflora bij zwaarlijvige, insulineresistente mannen door antibiotica geen grote invloed had op het metabolisme van de gastheer. Het ontbreken van metabole effecten kan verband houden met de korte blootstelling aan antibiotica in vergelijking met de tijd die nodig is om het metabolisme van de gastheer te beïnvloeden. Een ander kritiekpunt is dat in deze studie geen diepgaande sequencing methoden werden gebruikt om de darmflora te karakteriseren. Hierdoor zijn mogelijke veranderingen in bacteriën die niet werden gerepresenteerd door probes op de microarray gemist. Gezien deze gegevens is er behoefte aan langer durende interventiestudies in mensen waarbij met geavanceerde 
microbiota analysetechnieken wordt onderzocht of manipulaties van de darmflora kunnen bijdragen aan een veranderd menselijk metabolisme.

Hoofdstuk 4 richtte zich specifiek op de effecten van de antibioticabehandeling (1500 $\mathrm{mg} /$ dag amoxicilline of vancomycine versus placebo) op de plasma aminozuurspiegels in mensen omdat er steeds meer aanwijzingen zijn dat aminozuren belangrijke factoren zijn die ten grondslag liggen aan de ontwikkeling van obesitas. Deze studie toonde aan dat de amoxicilline-behandeling specifiek de plasma concentraties van vertakte aminozuren verhoogde in vergelijking met placebo, terwijl de vancomycine behandeling geen significante effecten op de plasma concentraties van enige aminozuren liet zien. Belangrijk is dat alleen vancomycine behandeling de samenstelling van de darmflora aanzienlijk beïnvloedde met een afname in Gram-positieve bacteriën van de Firmicutes phylum. Omgekeerd vertoonden Gram-negatieve bacteriën een verhoogde aanwezigheid na behandeling met vancomycine. Omdat darmbacteriën vertakte aminozuren kunnen afbreken, is het mogelijk dat de verschuiving in de darmflora-samenstelling na vancomycine behandeling verantwoordelijk is voor een hogere afbraak van vertakte aminozuren in die groep. Bacteriën produceren namelijk zeer actieve peptidasen. Wat betreft de dikke darm lijkt het erop dat aminozuren waaronder lysine, arginine, glycine en de vertakte aminozuren leucine, valine en isoleucine de voorkeurssubstraten zijn van darmbacteriën. Of dit de beschikbaarheid van de vertakte aminozuren heeft beïnvloed, moet nog worden bestudeerd. Toekomstige studies zouden zich dan ook moeten richten op de mechanismen die ten grondslag liggen aan de veranderde vertakte aminozuur concentraties in relatie tot insulineresistentie. Zoals eerder vermeld heeft het gebruik van een microarray om de darmflora te profileren mogelijk de detectie van bepaalde microbiële veranderingen in de amoxicilline groep gemaskeerd die verband kunnen houden met verhoogde vertakte aminozuur concentraties.

Omdat kennis over de uitwisseling van aminozuren tussen buikorganen bij mensen schaars is, wordt een uitgebreid overzicht van het menselijke aminozuurmetabolisme weergegeven in Hoofdstuk 5. Met het oog op de steeds meer erkende rol van de darmflora in het aminozuurmetabolisme en energiemetabolisme werd er speciaal onderscheid gemaakt tussen de dikke darm en de dunne darm. De uitwisseling van aminozuren tussen de verschillende buikorganen werd onderzocht in een chirurgische setting waarin twintig patiënten een Whipple-operatie ondergingen. Tijdens deze operatie werd tegelijkertijd bloed afgenomen uit de polsslagader en verschillende aderen (v. portae hepatis, v. hepatica, v. mesenterica superior, v. mesenterica inferior, v. lienalis, v. renalis). Dit bood de mogelijkheid om de bijdrage van het ileum samen met het proximale colon, het distale colon, de portaal gedraineerde ingewanden, het splanchnisch gebied, de lever, de milt en de nieren te kwantificeren bij het produceren of extraheren van aminozuren. De gegevens onthulden dat de bekende intestinale glutamine-citrulline-omzetting functioneel lijkt te zijn in het ileum en het proximale colon, maar niet in het distale colon. De algehele bevinding dat de distale darm slechts kleine arterioveneuze verschillen vertoonde, is interessant gezien de voorgestelde rol van darmbacteriën in het aminozuurmetabolisme. Het is mogelijk dat aminozuren 
niet significant worden geabsorbeerd door de darmwand van het colon, maar eerder intensief worden gemetaboliseerd door de aanwezige darmbacteriën. Aangezien de darmflora samenstelling door het maagdarmkanaal verschilt is het bacteriële aminozuurmetabolisme in de darm waarschijnlijk compartiment specifiek. In het kader van de gezondheidsclaims van pre- en probiotica geeft de huidige studie een gedetailleerd beeld van de fysiologie van het menselijk aminozuurmetabolisme. Als vervolg op deze studie en in het kader van de steeds toenemende interesse in functionele voedingsmiddelen die de samenstelling van de darmflora en daarmee ook haar producten beïnvloed, werd ook de uitwisseling van de korte keten vetzuren tussen de abdominale organen in dit unieke menselijke model onderzocht en gepresenteerd in Hoofdstuk 6. Het lijkt erop dat het distale colon de belangrijkste speler is in de afgifte van korte keten vetzuren aan de bloedbaan, gevolgd door het proximale deel van de darm welke slechts voor een derde bijdraagt aan de korte keten vetzuur afgifte. Dit kan erop wijzen dat een groter deel van de korte keten vetzuren worden gemetaboliseerd door het darmslijmvlies van de proximale darm, omdat de meeste korte keten vetzuren worden geproduceerd in de proximale darm. Het feit dat de samenstelling en activiteit van de darmflora verschilt tussen de proximale en distale darm kan bijdragen aan de huidige bevindingen. Bovendien is het bekend dat de korte keten vetzuren receptoren (GPR41 en GPR43) voornamelijk voorkomen in het ileum en het caecum. Een recente studie gaf aan dat de distale darm de meest geschikte locatie was om gunstige metabole effecten op te wekken, aangezien distaal maar niet proximaal toegediend acetaat een duidelijke toename in vetoxidatie en circulerende concentraties van het verzadiging stimulerende hormoon (peptide YY) veroorzaakte. Al met al kunnen deze bevindingen leiden tot de ontwikkeling van voedingsstrategieën en voedselproducten die specifiek de korte keten vetzuren productie in het distale deel van de dikke darm moduleren waardoor de metabole gezondheid gunstig wordt beïnvloed. Tenslotte kan worden geconcludeerd dat de lever efficiënt korte keten vetzuren aan de bloedbaan onttrekt.

Omdat de lever een belangrijk orgaan blijkt te zijn dat bijna alle korte keten vetzuren uit de circulatie onttrekt, ontstond de vraag welke impact een situatie van acuut verlies van leverfunctie zou hebben op systemische korte keten vetzuur concentraties. Hoge systemische butyraat concentraties kunnen bijvoorbeeld nare bijwerkingen veroorzaken zoals hypokaliaemie en misselijkheid. In Hoofdstuk 7 werd derhalve de korte keten vetzuren klaring door de lever bestudeerd na een acuut, hoewel gecontroleerd, verlies van leverfunctie in mensen. In deze studie werd voor en na leverresectie bij 30 patiënten bloed afgenomen uit de polsslagader, poortader en leverader. Er werd aangetoond dat de darm aanzienlijke hoeveelheden acetaat, propionaat en butyraat produceerde, zowel voor als na leverresectie. Terwijl de opname van propionaat door de lever niet significant verschilde voor en na resectie, nam de opname van acetaat en butyraat door de lever aanzienlijk toe. Als zodanig waren arteriële korte keten vetzuur concentraties niet verschillend voor en na leverresectie. Concluderend heeft acuut leverweefselverlies geen invloed gehad op de systemische concentraties van de korte keten vetzuren, hetgeen betekent dat de lever een grote reservecapaciteit heeft om propionaat, acetaat en butyraat te metaboliseren en een toename van arteriële concentraties te voorkomen. 
Dit werd nog eens onderstreept door de verhoogde opname van acetaat en butyraat door de lever na leverresectie en kan worden geïnterpreteerd als indirect bewijs voor de veiligheid van suppletie met prebiotica, zelfs bij patiënten met een beperkte hoeveelheid leverweefsel.

In Hoofdstuk 8 worden de belangrijkste bevindingen van de onderzoeken in dit proefschrift beschreven en geïntegreerd. Ten eerste leverde het antibioticaonderzoek (gepresenteerd in hoofdstuk 3 en 4) unieke gegevens op van patiënten in een gecontroleerde setting. Deze studie leverde echter geen bewijs dat het veranderen van de darmflora invloed heeft op de metabole activiteiten in de mens, hoewel talloze onderzoeken veranderingen in de samenstelling en de metabolieten van de darmflora in verband hebben gebracht met het metabolisme van de gastheer. Toekomstig onderzoek is daarom nodig om de potentie van manipulatie van de darmflora in mensen met verschillende metabole fenotypes te valideren. In het ideale geval zou metagenomics worden toegepast om specifieke veranderingen in metabole routes te kunnen identificeren. Bovendien is meer klinisch onderzoek vereist om ons begrip te vergroten aangaande de toepasbaarheid van prebiotica als benadering om de gezondheid te bevorderen en/of ziekten te behandelen. In dat opzicht kan het interessant zijn om prebiotica toe te dienen aan patiënten die een operatie ondergaan terwijl tegelijkertijd bloed wordt afgenomen uit verschillende abdominale bloedvaten. Op deze manier kan worden onderzocht hoe prebiotica de uitwisseling van korte keten vetzuren en aminozuren door de abdominale organen beïnvloed. Bovendien kan dit inzicht geven in de effecten van prebiotica op de darm fysiologie aangezien het mogelijk is darmbiopten te verkrijgen tijdens deze chirurgische ingreep. 